\title{
The Influence of Economic Growth of Middle Society in the New Normal Era Based on Information Technology Applications in Central Kalimantan
}

\author{
Yely Ondrie \\ Postgraduate Program in Economy Sciences, Universitas Palangka Raya, Indonesia \\ yelyondrie22@gmail.com
}

\begin{abstract}
The main objective of this research is to determine the positive and negative impacts of the economic growth of the middle class in the new normal era based on information technology applications in Central Kalimantan. This research uses descriptive analysis, the type of data used is primary data and secondary data. The results of the research are three variables that are very influential on the economic growth of the middle class, namely natural resources, human resources, and capital stock. Meanwhile, the most influential is human resources or labor. The positive side of society has creativity in maintaining the family economy from all aspects using technological progress and sufficient capital accumulation. The negative impact for the middle and lower class communities, many employees of oil palm plantations and also other companies were terminated for an unclear period of time, the small business sector, such as the procurement of basic necessities, is sometimes not a cheap price but there are commodities that are more expensive due to lack of supply.
\end{abstract}

Keywords

economy, technology, newnormal

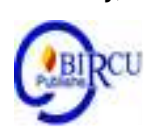

\section{Introduction}

Central Kalimantan is a province in Indonesia on the island of Borneowith the capital city of Palangka Raya, with an area of $153,564.50 \mathrm{~km} 2$ or about 8.02 of the total territory of Indonesia, with a population of around 2.5 million people. The area is approximately 15.4 million hectares, of which 13.0 million hectares are forest and 2.7 million hectares are peatlands.

Central Kalimantan which is nicknamed Bumi Tambun B Sungai with the Motto Isen Mulang (Sangen Language: Persistent). The tribe in Central Kalimantan are Dayak tribe $(46.62 \%)$, Java tribe $(21.67 \%)$ and Banjar tribe $(21.03 \%)$. The tribes inhabit several areas, namely the main area of the Dayak ethnicity in the interior, the main area of Javanese ethnicity, namely the transmigration area and the main area of the Banjar ethnic group, namely the coastal and urban areas. Over time, the three tribes are partially integrated in the City.

The natural resource potential of Central Kalimantan is dominated by $80 \%$ forest area. The remaining primary forest is about $25 \%$ of the total area. From this area of land began to be dominated by oil palm, rubber and rattan plantations which were spread almost throughout the region, besides that natural resources that had been exploited were coal, gold, zircon, iron, copper, kaolin, gemstones and others.

Economic development in Central Kalimantan before the occurrence of the corona covid-19 virus experienced very good growth, this can be seen from the level of welfare of the community both in rural areas and in cities, it is almost rare to hear unemployment, this is 
based on data from the Central Kalimantan Provincial Statistics Agency, which states that Central Kalimantan Province Human Development Index (IPM) by Regency / City, 20102019 experienced a very significant increase from year to year.

The presence of the Corona or Covid-19 Virus on the Earth of Central Kalimantan has an impact on the socio-economic and cultural life of the people in Central Kalimantan, even this virus is worrying, and this is monitored from MMC.Kalteng.go.id the number of cases continues to increase.

The impact of the spread of the corona virus outbreak or Covid-19 is specifically felt by all levels of society, apart from the health sector, one of the most influential impacts is the economic sector of the middle and lower class. Wnevertheless, the living conditions of the people side by side with the existence of Covid-19 towards the New Normal Era, still have a positive and negative impact on the lives of the people of Central Kalimantan, for this reason this paper raises the title The Influence of Economic Growth of a Middle Society in the New Normal Era Based on Information Technology Applications in Central Kalimantan.

\section{Review of Literature}

Economy is a vital thing in a country. Because the economic aspect is the main measure of people's welfare, because the people's welfare is one of the main goals of achieving national interests, it is not surprising that the economy is often the main focus for every country in managing governance. Therefore, the State must have an important concept for economic growth, besides the concept of economic development, this concept must be understood so that the direction and goals of a nation are clear.

Economic growth is still an important goal in a country's economy, especially for developing countries like Indonesia. Economic growth must also be followed by positive changes in the context of improving the welfare and prosperity of the people who are mandated by the 1945 Constitution. Therefore, economic development is still the focus of development in Indonesia and is an indication of the success of development. Economic growth is a process of increasing the production capacity of an economy that is realized in the form of an increase in national and regional income. (Magdalena and Suhatman)

According to experts, the theory of economic growth is the development of activities that cause an increase in the amount of production of goods and services in a country. This means that growth in general is an expression that describes a level of development. It can be understood that this economic growth is used to measure the achievements achieved in the development of an economy. This development can be seen from the increase in a country's Gross Domestic Product (GDP).

The definition of Gross Domestic Product (GDP) itself is the sum of the value of goods and services produced by all people in a country for one year, including those produced by foreign nationals residing in the country's territory. Therefore, economic growth can also be interpreted as a state of the economy that shows an increase in a country's Gross Domestic Product (GDP) when compared to the previous year. In contrast to economic development, the calculation for economic growth ignores whether the increase is greater or less than the existing population growth. So that the calculation of economic development also does not see whether or not there are changes in the economic structure.

Economic growth data of a country, using data in quantity, to compare between one period and another. To be able to record the number of units of goods and services produced by the community in real terms is very difficult. This is due to differences in the unit of measurement for each item, as well as the various types of goods and services produced. For 
example, the unit of measurement for rice production uses units of $\mathrm{kg}$ or $\mathrm{kw}$ or tonnes, while calculating petroleum production uses units of volume or barrels. Meanwhile, the service sector, its production cannot be measured physically. For example, in communication operator services, transportation services, tourism services, consulting services, lodging services and others.

Basically, every country certainly wants to experience economic growth with positive values from year to year. It's just that, often what happens is a country's economic growth in real terms is not in accordance with its potential economic growth. Economic growth for a country is indeed good, however, it should also be noted that economic growth that is too high and too rapid is also not good, because it can lead to inflation or an increase in the price of goods. However, if what happens is an economic slowdown, then this could lead to an increaseunemploymentwhich means that the welfare of the community is reduced. For this reason, the state needs to continue to maintain a stable economic growth cycle.

Economic actors, basically have very important functions. Because it has two functions at once, namely as a supplier of all the needs of the community, both primary, secondary and tertiary. At the same time, they also function as absorbers of community labor, which can economically increase purchasing power. These economic actors can be individuals, business entities not legal entities. (Ansari, 2019)

The relationship between inflation and economic growth is one of the debatable issue and the most important macroeconomic discussions among macro economists, policy-makers and monetary authorities in all countries. Particularly, whether inflation is necessary or harmful form economic growth constitutes the basis of the matter in question (Eden in Wolli, 2018).

Economists argue that in order to understand the concept of economic growth in a society in a country, we can study the theory of economic growth which is classified into several groups, namely classical theory, neoclassical theory, Neokeynes theory, WW Rostow theory, and Karl Bucher theory.

1. The classical theory is the theory of economic growth developed since the 17th century, with two of the most influential figures, namely Adam Smith and David Ricard According to Adam Smith in his book, entitled An Inquiry into the Nature and Causes Weaklth of Nation (1776), describes how to analyze economic growth through two factors, namely the total output factor and the population growth factor. The calculation of total output is carried out with three variables, including natural resources, human resources, and capital stock. Meanwhile, the second factor, namely population growth, is used to determine the market area and the rate of economic growth. According to David Ricardo, the best known economic growth is about the law of diminishing returns. His thinking is about how population or workforce growth is able to affect the decline in marginal products due to the limited amount of land. According to him, increasing labor productivity really needs technological progress and sufficient capital accumulation. Thus, economic growth can be achieved.

2. Neoclassical Theorynamely economic growth, the two most popular figures were Joseph A Schumpeter and Robert Solow. According to Joseph A Schumpeter in his book entitled The Theory of Economic Development, discusses the role of entrepreneurs in development, which concludes that the process of economic growth is basically a process of innovation carried out by innovators and entrepreneurs. Meanwhile, according to Robert Solow, economic growth is a series of activities originating from four main factors, namely humans, capital accumulation, modern technology and output.

3. Neokeynes theory, according to Roy F. Harrod and Evsey D Domar. The views of the two figures are about the influence of investment on aggregate demand and growth in 
production capacity. This is because this investment can then increase economic growth. This Neokeynes theory holds that investment is a very important component in the process of determining the success of economic growth.

4. W. W Rostow's theory, discussed a lot about economic growth and development theory. His various thoughts are contained in one of his books entitled The Stages of Economic, A Non-Commons Manifesto. In this book, Rostow uses a historical approach to describe the process of economic development that occurs in a society. According to him, in a society, the process of economic growth takes place in several stages, including:

a. Traditional society (traditional society)

b. The prerequisite stage for take off (praconditions for thae off)

c. The take off stage

d. The stage towards maturity (maturity)

e. High consumption stage (high mass consumption)

5. Karl Bucher's theory also has its own opinion about the stages of economic development that take place in a society. The stages of economic growth according to Karl Bucher are:

a. Production for their own needs (closed household)

b. The economy as a form of expanding the exchange of products in the market (urban households)

c. National economy with an increasingly important trade role (country household)

d. Trade activities that have expanded across national borders (world households)

The new regional growth theory believes that the biggest factor at play is the power of technology and innovation in the region. In addition, these two things need to be supported by quality human resources so that there is a need for investment in human resource development. According to this theory, the factors affecting economic growth are divided into 2, namely economic factors (such as natural resources, technological advances, etc.) and non-economic factors (such as human resources, social factors, etc.).

According to Tarigan (2005), the rate of economic growth in a region is determined by the amount of increase in exports in that region. In his theory, the economic basis is divided into 2, namely the base sector and the non-base sector. The basic sector is the economic sector that has succeeded in meeting the needs of the regional market while exporting its products. Meanwhile, the non-base sector is a sector that can only meet the needs of regional markets. The analysis used to identify which sectors are based and which are non-basis is the Location Quotient analysis (LQ).

The phenomenon of economic growth has occurred since time immemorial so that many experts argue and formulate theoryaround economic growth and development. The theory originated from the results of ancient thoughts along with the times and ages so that it became modern. This means that the theory also changes according to conditions and situations. The progress of a country can be seen from the level of economic strength supported by infrastructure. It can be said that the prosperity of society is measured based on economic strength and social welfare. The growth of a country's economy at the same time stimulates the acceleration of development. So that development will occur evenly and dreams of a prosperous community life will be realized.

The world is currently carrying out the globalization of the industrial revolution 4.0, with the development of information technology that is increasingly rapidly influencing the growth and development of social, economic and cultural life. Especially now that the presence of Covid-19 in Central Kalimantan has greatly shaken the socio-economic and cultural life, in dealing with it so that it forces the Government and the community to work hand in hand to be able to overcome the deadly virus, using all limited facilities and capabilities. From this it provides a logical consequence which states the importance of 
changes in meeting and supplying community needs, to provide solutions to problems so as to produce comprehensive problem-solving alternatives.

The transmission of the corona virus in Indonesia is no exception, Central Kalimantan Province, which continues to occur. This can be seen from the latest information regarding the number of cases and data on Covid-19 patients on Sunday (26/7/2020) afternoon Kompas.com, which was announced by the government. Even in a period of nearly six months, the number of Covid-19 cases in Indonesia has almost reached 100,000 people. The current life situation runs side by side between Covid-19 and the new normal.

The new normal process in the midst of a corona pandemic is indeed not easy. The community needs to adapt to environmental conditions, while maintaining the body and mental health of the family, in order to avoid the coronavirus outbreak.Some of us may still not be able to understand what a new normal or new normal actually is. Chairman of the Expert Team for the Task Force for the Acceleration of Handling Covid-19, Prof. drh. Wiku Adisasmito, M.Sc., Ph.D., stated that the new normal is a situation that must be lived by the community in the midst of the Corona pandemic, which is marked by adjusting our behavior to health protocols in daily activities. It can be concluded that, the new normal is basically the formation of new behavior.

According to Dr. Maharsi Anindyajati, M.Psi., Psychologist - Head of Center for Human Capital Development PPM Management,To form a new behavior requires a new mindset or mindset. Starting with the thought that now we really have to change our behavior in order to adapt to this condition. The situation in the future will not be the same as the previous situation. Stop questioning when we will return to life like before this Corona pandemic occurred.

According to Lawrence Kohlberg, a character who introduced the theory of moral development, adjusting behavior for the sake of the common good is a form of moral reasoning at the post-conventional level, which should occur in adults. But in reality, not everyone who has entered adulthood is at this moral level. Thus, our adherence to health protocols will reflect the level of our moral development.

Quoting what was said by BF Skinner, a psychologist who is well known for his theory of behavior formation that a society consisting of people who behave cooperatively will tend to survive. Ultimately, our mindset will determine whether our society will survive or not.

According to Lani Sidharta (1995: 11), "An information system is a man-made system that contains an integrated set of manual components and computerized components that aim to collect data, process data, and produce information for users."Martin (1999), is not only limited to computer technology (hardware or software) used to process and store information, but also includes communication technology to transmit information.

The development of information technology is currently very rapid, even in remote areas that previously had not experienced technology can now enjoy online information technology services. However, differences in information systems and information technology often make us confused to distinguish between information systems and information technology. In order to better understand, we first learn the meaning of information systems with this information technology;

1. Understanding Information Systems (SI) is a combination of information technology and the activities of people who use that technology to support operations and management. In a very broad sense, the term information systems is often used to refer to the interactions between people, algorithmic processes, data and technology.

2. Understanding Information Technology is a technology used to process data, including processing, obtaining, compiling, storing, manipulating data in various ways to produce quality information, namely information that is relevant, accurate and timely, which is 
used for personal, business, and governance and is strategic information for decision making.

The difference between Information Technology and Information Systems is that information systems cover all systems within the company as a whole including information technology, accounting, management, and others in it, while information technology exists to help / support information system activities, including making hardware, software, networks, databases, and others.

\section{Reseach Method}

This research uses descriptive analysis. The data taken is data related to the influence of the New Normal Era of Middle Society Economic Growth Based on Information Technology Applications. The object of research is Central Kalimantan Province. The types of data used are primary data and secondary data.

Data collection is carried out through several sources on trusted news pages such as detik.com, several opinions from experts and several journals that are used as references. After collecting data, data analysis is then carried out to find out what influences the New Normal Era of Middle Economic Growth.

\section{Discussion}

Central Kalimantan has natural resources that are very potential, seen from the domination of $80 \%$ forest area. The remaining primary forest is about $25 \%$ of the total area. Of this land area, oil palm plantations reach 700,000 ha (2007). Community rubber and rattan plantations are still scattered in almost all regions, especially in the districts of Kapuas, Katingan, Pulang Pisau, Gunung Mas and Kotawaringin Timur. In addition, there are natural resources that have been cultivated in the form of coal, gold, zircon, and iron mines. There are also copper, kaolin, gemstones and others.

From the conditions and natural resources that are able to increase the growth and economic development of the people in Central Kalimantan, this can be seen from the average level of welfare of the middle to lower class both in rural and urban areas, and it is almost rare to hear unemployment. Based on data from the Central Kalimantan Statistics Agency, Central Kalimantan Province stated that the Human Development Index (HDI) of Central Kalimantan Province by Regency / City, 2010-2019 experienced a very significant increase from year to year.

The presence of the Corona Virus or covid-19 has a broad impact on all levels of society, especially the health sector, and what is more influential is the economic sector of the middle to lower class. The economy suddenly seems like suspended animation, all people are confused and afraid. Based onmonitoring from MMC.Kalteng.go.id the number of cases continues to increase, even more worrying resulting in activity restrictions To reduce the spread of Covid-19, the Covid-19 Handling Task Force continues to appealso that people continue to comply with the health protocol rules from the Government, in hopes of stopping the pandemic sooner.

Current conditions of community life, coexistence with the existence of Covid-19 has positive and negative impacts on economic growth. Three variables that are very influential, namely natural resources, human resources, and capital stock. Meanwhile, the most influential is human resources or labor, which are used to determine the market area and the rate of economic growth. 
The positive side of society is demanded to have creativity in maintaining the family economy from all aspects, which means that increasing labor productivity really requires technological progress and sufficient capital accumulation. The country has made an important concept for economic growth and development. The concept is implemented in order to realizeMandate of the 1945 Constitution. The state is obliged to increase economic growth, becauseeconomy is the main measure of people's welfare, no wonder the economy is the main focus in structuring the government of national interests for a country.

The negative impact for the middle and lower income community experienced severe shocks such as many employees of oil palm plantations and also other companies who were forced to lay off their employees for an unclear period of time, not to mention from the small business sector such as the procurement of basic foodstuffs and others, which sometimes is not the price which is cheap but there are commodities that are more expensive due to lack of income.

The new order requires adaptation to changing strategies in restoring economic growth. The impact of the Covid-19 pandemic has encouraged middle-class people to innovate in utilizing Information Technology (IT) in managing their business. Withtechnological advances that are getting faster and faster certainly make many changes to economic growth and development, such as; 1). Exchange of information that becomes easier and faster, 2). Make work easier and 3). Work that can be done by one person becomes more effective and efficient. While the negative effects, 1). Mthe introduction of an external culture that is not easy for children to accept in Indonesia, especially in regions, 2). Excessive use of gadgets and ultimately can damage brain development in children, 3). Lack of socializing people, because the focus is always on technology.

The functions and benefits of technology today are that it provides a lot of benefits for the survival of one example of a technology that is really useful is Google. In general, it makes it easy for users to be able to do everything in a faster and shorter way, all of which also makes the resulting work better. In particular, it helps to educate children so that they are no longer tech-savvy and can make it easier to adapt to their surroundings. In addition, technology can also be used as a means of exploration to add insight and knowledge in completing work.

One proof of technological developments in the financial world is the emergence of financial technology (fintech). Thanks to the financial system, this fintech provides many benefits such as the ease of financial services, helping to make it easier for unbankable SMEs to get business capital and of course financial inclusion. With the ease of financial services offered by technology in the financial world, it is this that allows people to make good use of it, one of which is by developing funds in a fintech.

The application of the new normal is a very urgent change in life patterns and behavior. The current pattern or order of people's lives is assisted by technological developments in the era of the industrial revolution 4.0, so that the current information system forces the public to understand and understand how to use and use it to meet their daily needs, even many middle-class business people who are able to carry out their business by online. 


\section{Conclusion}

Another mindset that can be instilled is that new normality is not just a demand to adapt and form new behavior, but also an opportunity to make ourselves better, namely to be positive, have morality and be sensitive to the interests of others.

One proof of technological developments in the financial world is the emergence of financial technology (fintech). This financial system from fintech provides many benefits such as the ease of financial services, helping to make it easier for unbankable Small and Medium Enterprises (UKM) to get business capital With the ease of financial services offered by technology in the financial worldthe economic growth of the middle class in the new normal era is able to survive and even promote better economic development

From several things that have been discussed above, it is concluded that technological developments can cause positive and negative things. To be able to suppress negative things that can affect ourselves, we must manage the progress of this information technology properly.

\section{References}

Ansari, T. (2019). Reminding State Owned Enterprises (BUMN) Management Using the Principle of 'Business Judgment Rule': A Preliminary Note. Budapest International Research and Criticsc Institute-Journal (BIRCI-Journal). P. 27-38

Magdalena, S and Suhatman, R. (2020). The Effect of Government Expenditures, Domestic Invesment, Foreign Invesment to the Economic Growth of Primary Sector in Central Kalimantan. Budapest International Research and Critics Institute-Journal (BIRCIJournal). P. 1692-1703.

Mariana, Made Suyana Utama, and Ida Bagus Purbadharmaja. "Pengaruh Pertumbuhan Investasi, Pertumbuhan Penyerapan Tenaga Kerja Terhadap Pertumbuhan Ekonomi Dan Perubahan Struktur Ekonomi Di Provinsi Bali.” E-Jurnal Ekonomi dan Bisnis Universitas Udayana, no. VOLUME 03.NO.06.TAHUN 2014 (2014).

Tapia, Pablo, Michael Thelander, Timo Halonen, Jeff Smith, and Mika Aalto. "Smartphone Performance." HSPA+ Evolution to Release 12: Performance and Optimization 9781118503 (2014): 293-335.

Shaw, Ian, and Nick Gould. Qualitative Research In Social Work. London: SAGE Publications London, 2001.

Wollie, G. (2018). The Relationship between Inflation and Economic Growth in Ethiopia. Budapest International Research and Critics Institute-Journal (BIRCI-Journal). P. 264271.

Walliman, Nicholas. Social Research Methods. London - Thousand Oaks • New Delhi: SAGE Publications India Pvt Ltd, 2006.

https://portal-ilmu.com/teori-teori-pertumbuh-ekonomi/

https://travel.detik.com/detiktravel/d-5117395/7-provinsi-ter Luas-di-indonesia-tak-ada-daripulau-jawa

https://www.kompasiana.com/181910501059callistaa/5d99c03e0d82303fee05a622/teoripertentuk-ekonomi

https://ppm-mana Manajemen.ac.id/id_ID/blog/artikel-mana Manajemen-18/post/newnormal-new-mindset-new-habit-new-us-1802

https://idtesis.com/pembahasan-l Lengkap-teori-sistem-informasi-teknologi-informasimenurut-para-ahli-dan-contoh-tesis-sistem-informasi-teknologi-informasi/

https://www.akseleran.co.id/blog/perkembangan-teknologi/ 